\title{
特集「観光と不動産」にあたって Tourism and Real Estates
}

中井 検裕（東京工業大学, 出版編集委員長) Norihiro NAKAI

ここ数年のインバウンド観光の伸びは，目をみはるものがある。2013年には年間 1 千万だった 訪日外国人数は, 2015 年には約 2 千万人となり，2017年には 2 千 8 百万人を超える数值を記録し た。2018年については，9月に入り，まず台風21号によって関西国際空港が 2 週間にわたり利用 不可能もしくは利用制限されたこと, また 9 月 6 日には北海道胆振東部地震が発生し, これらの 影響が心配されたところだったが，10月までで 2 千 6 百万人を達成し，このペースでいけば年間 3 千万人を突破するのは確実な情勢である。

インバウンド観光については, 政府の目標も 2020 年には 4 千万人, 2030 年には 6 千万人と, そ の成長にかける期待は極めて大きい。しかし期待が高いのはインバウンド観光だけではない。国 内観光にあっても高齢化社会における余暇時間の増加を背景として観光への期待は高まってお り, 特に人口減少が顕在化している地方都市では交流人口の増加, 観光による経済振興をねらっ て，観光を地域活性化の切り札と考えているところも少なくない。

観光の発展は, 経済的なメリットにより地域の振興にプラスの影響を与えている場合もあれば, テーマパークの失敗, 観光客による迷惑行為など, マイナスの影響もある。功罪両面があるとし ても, 人口減少・超高齢化社会を迎えた我が国においては, 観光が医療・福祉とならんで, 成長 が期待できる数少ない産業であることはまちがいない。当然, 地域や地域を構成する不動産に与 える影響も少なくなかろう。こうした状況を背景に, 観光が地域の経済と不動産に与える影響を 議論することを目的として，本特集を企画した。

本特集には全部で 8 編の論説が収録されている。

最初の 3 本の論説（西山論説, 十代田論説, 宗田論説）は, 視点の違いはあるもののいずれも 「観光まちづくり」を取り扱ったものである。西山論説「観光と不動産の新たな関係構築を考え る」は, 不動産, とりわけ歴史的な不動産に焦点をあて, 21 世紀の観光まちづくりは, 20世紀の 観光開発とは異なり, 地域そのものの価值を向上させる新たな試みとして期待すべきものと論じ ている。十代田論説「新しい観光による地域活性化の課題と方向性」は, 新しい観光ニーズであ るオルタナティブ・ツーリズムと従来のマス・ツーリズムを対比させながら, 観光まちづくりの 可能性と課題を論じたものである。宗田論説「観光まちづくり：観光と住民生活の暮藤」は，い わゆる観光公害を取り上げ，京都やヨーロッパの歴史都市がある意味したたかにそれらに対応し てきた様が整理されて描かれている。

残りの 5 本の論説は, 観光に関する個別のテーマとして, リゾート開発（山田論説）, IR (美原 論説), ホテル (小松論説), 民泊 (中川論説), そして現在, 地域の観光マネージメント主体と して注目されているDMO(大社論説) を取り扱ったものである。いずれも日本不動産学会誌にふ さわしい内容となっており，ぜひ通読してみてほしい。 